\title{
Conceptual Bases of Full Realization of Women's Labour and Entrepreneurial Activity
}

\author{
Zulfiqarova Dilfuza Gulomjanovna ${ }^{1}$, Saidboev Shermirza Dotkamirzaevich ${ }^{2}$, Rashidov Rahmatullo \\ Alojonovich ${ }^{3}$ \\ 1,2,3 Namangan Institute of Engineering and Technology, Namangan, Uzbekistan \\ * Rashidov Rahmatullo Alojonovich. Namangan Institute of Engineering and Technology, Namangan, Uzbekistan \\ r.rashidov84@mail.ru
}

\begin{abstract}
Today, the problem of poverty has emerged as a global problem in all countries of the world. Due to the difference in economic development, poverty is different and has a relative meaning. Prevention and reduction of poverty and improving the quality of life of the people, increasing the interest and aspirations of women in women's entrepreneurship, creating favorable conditions for the development of their entrepreneurial activities are the main foundations of today's reforms. In a country where there is a gap between the incomes of the population, it is clear that there will be poor people. Therefore, poverty cannot be eradicated, but it can be reduced through the development of entrepreneurship. The poverty rate is inversely proportional to the economic level of the country, i.e., in developed economies, the poverty rate is low, and in weak economies it is high. The whole world has turned its attention to solving this problem.

The accession of the Republic of Uzbekistan to global economic processes requires more active participation of women in the economic life of the country. Entrepreneurship is becoming an independent factor of women's sexual freedom in the economic sphere. At a time when society is renewing and entering the world economy, the development of women's entrepreneurship is encouraged. This is the main source of development of the real sector of the economy.

Through the socio-economic development of women's entrepreneurship, it is possible to observe a certain positive effect on achieving sustainable economic development of the country, especially in the prevention of poverty. This article highlights the role of women's entrepreneurship in the country's economy and the problems in its development and their solutions, conclusions and recommendations.
\end{abstract}

Keywords

Economy, Women's Entrepreneurship, Income, Gross Domestic Product, Demography, Unemployment, Poverty, Employment.

\section{Introduction}

The study of the essence, importance and necessity of women's entrepreneurship in the socio-economic life of the country is a topical issue of scientific research. Scientific, theoretical and methodological study of the peculiarities of its formation, sustainability and development, assessment of the impact on the social status of the population, ensuring the effective organization of women's entrepreneurship in the regional economy are among the priorities of the national economy. Women's entrepreneurship plays an important role in the employment of the able-bodied population, the transition of the economy to an importsubstituting and export-oriented basis. The reason for this is explained by the seriousness of the demographic situation. The growing population is creating new problems related to employment. Women's entrepreneurship can play a positive role in solving problems.

They are:

- GDP per capita lags far behind the world average. This figure is $\$ 1,741$ in our country;

- The persistence of demographic pressure in our country has led to an increase in unemployment and poverty. There are now 4-5 million poor people;

- As a result of maintaining a strong demographic situation in the labor market, there is a problem of creating enough jobs. The results led to an increase in poverty.
As a result of the economic policy pursued in the country for the development of women's entrepreneurship, a significant positive shift is observed. A number of measures have been taken to further develop women's entrepreneurship, make full use of available resources, production and labor potential, and thus create new jobs, saturate the domestic market with local goods.

\section{Analysis of the relevant literature}

The almost equal proportion of women $(50.3 \%)$ and men (49.7\%) in Uzbekistan indicates the potential for the development of women's entrepreneurship. According to the Chamber of Commerce and Industry of Uzbekistan, the total number of women entrepreneurs is 52,000 , or $10 \%$ of the total number of business entities. More than $82 \%$ of women work in health and social services, and less than $10 \%$ in science, education, culture and the arts 1 .

\footnotetext{
${ }^{1}$ https://stanradar.com/news/full/34302-zhenskoe-litsouzbekistanskogo-biznesa.html
} 


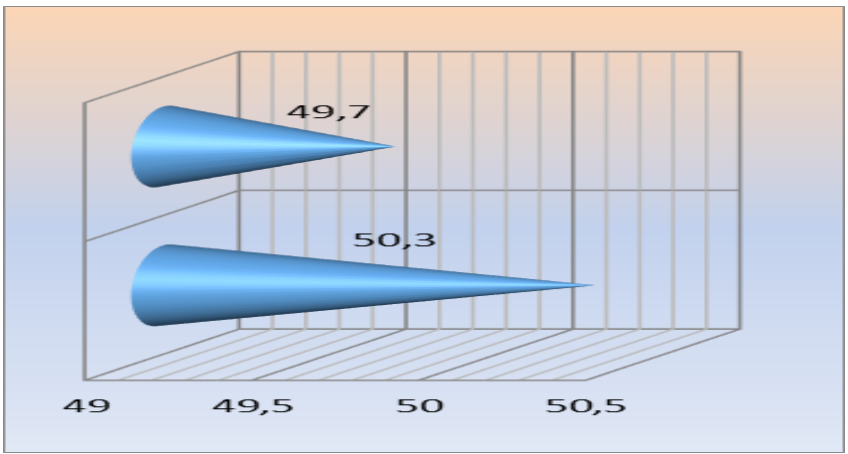

Figure 1. The ratio of women to men

Entrepreneurial activities by women are longer lasting than those of the stronger sex. With true hopes and dedication, the woman is more determined than others to follow the plan to ensure the continuity of enterprise production. In practice, women show a tendency to compromise, a desire to take into account ethical principles and norms when entering into a partnership. They pay special attention to the social aspects of entrepreneurial activity. Women entrepreneurs show a desire to be on an equal footing with all levels of government. The main purpose of this is not primarily a sense of financial interest, but the fact that the state is focused on raising the legal status and providing adequate information, raising the status of women's entrepreneurship. Thus, the modern female entrepreneur can be described as follows: she has professional and great creative abilities, characterized by such qualities as perseverance, responsible approach, organization and careful handling of economically risky operations. These allow for a high level of administrative and financial control, selection of employees, proper provision of incentives, leadership of the team among related enterprises.

In order to attract more women to entrepreneurial activities, it is very important to create conditions to free them from the usual household chores. Creating opportunities for child care, such as increasing the number of children admitted to preschools, allows women to set aside time to organize and run their own businesses.

\section{Research methodology.}

Methods of observation, comparison and systematic analysis were used in the study. The role of women's entrepreneurship in the economic development of the country is analyzed. Through the observation method, the level of poverty resulting from imbalances between the incomes of the population was observed in different countries and their results were compared. The role of women's entrepreneurship in preventing poverty was assessed.

\section{Analysis and results}

One of the main reasons for the lack of development of women's entrepreneurship is the high level of poverty in society. In order to further develop women's entrepreneurship in the country, in particular, to encourage women's entrepreneurship and innovative initiatives, the Presidential Decree No. PP-3856 of 14 July 2018 "On measures to improve and increase the efficiency of employment" including the creation of a number of favorable conditions for the involvement of women in entrepreneurial activities. Including:

- Individual entrepreneurs who have organized hairdressing services, tailoring services, shoe repair services in rural areas with a population of less than 5,000 people, as well as public baths are exempt from all taxes until July 1, 2023. was;

- Individual entrepreneurs are exempted from paying a fixed tax on each employee;

- to hire up to 3 permanent employees, enter into employment contracts with family businesses without a legal entity, as well as other close relatives of working age, including spouses of able-bodied children and grandchildren, able-bodied the right to involve older brothers and sisters, their spouses as participants in a family business entity without forming a legal entity;

- Individual entrepreneurs who received a microcredit for the first time at the expense of the Employment Promotion Fund are exempt from paying a fixed tax for 6 months from the date of its receipt;

- Also, the fixed tax rate for individual entrepreneurs providing freight services in road transport of more than 3 tons was unified, almost halved and set at 2 times the minimum wage.

They acknowledged that the status of women in society and providing them with decent work, as well as the creation of permanent jobs for women, as well as the extensive development of family business, home-based work, handicrafts, horticulture are still lagging behind. Critical conclusions also relate to the problems of organizing, managing, and providing financial resources for women's entrepreneurship.

It was noted that one of the main tasks is to improve the welfare of women and their social protection. In any country, there are low-income segments of the population. Poverty reduction means the awakening of entrepreneurial spirit in the population, the full realization of the inner strength and potential of man, the implementation of economic and social policies to create new jobs. Therefore, it is necessary to develop a poverty reduction program with the World Bank, the EBRD, the United Nations Development Program and other international institutions, and conduct a thorough study on the basis of international standards to create a new methodology that covers the concept of poverty, its criteria and assessment methods. It was emphasized that

In developed and developing market economies, there are different views on the concept of poverty by experts. In particular, economists from developed market economies A.Smith, J.M. Keynes, Y. Shumpeter, Paul E. Samoulson, N.H. Williams gave a number of definitions of the term poverty in their scientific research. According to I. Fisher, R. Dornbush, and R. Schmalenzi, poverty is morally and culturally constrained, although incomes are not physically viable enough to meet the needs of society within the current normative requirements of consumption. This is 
because they claim that their income will be much lower than the set level.

According to the Russian economist A.A Razumov, poverty affects various spheres of social life, there is a high level of negative barriers to the socio-economic development of a particular individual, family and society as a whole. This will lead to a deterioration in the quality of life of the population, an increase in socio-economic and gender inequality, and will be an obstacle to successful social development. Poverty is not just food and clothing, lack of housing, lack of access to education and health services that people need. And he described it as a lack of income for the population to get everything they need for life, at least to a minimum. A distinctive feature of poverty among the Russian population is that more than 50 percent of the Russian poor are able to work, and 42 percent of them are employed. The vast majority of the unemployed are women.

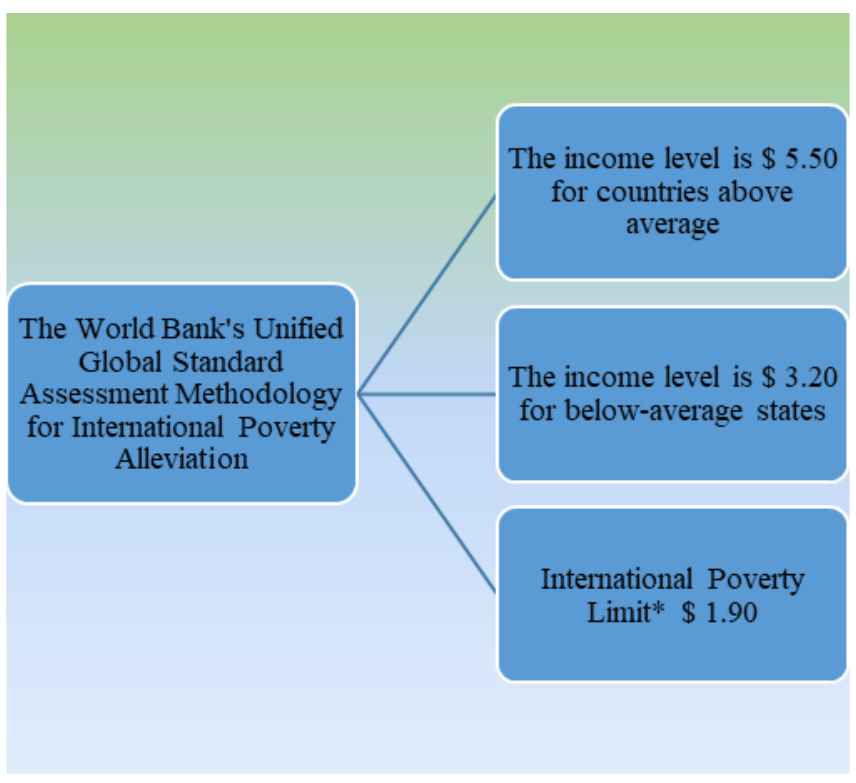

Figure 2. The World Bank's Unified Global Standard Assessment Methodology for International Poverty Alleviation

* The international poverty line was $\$ 1.9$ per person per day

Earnings of \$ 1.9 per person per day are the lowest level of poverty. Based on this measure, we can say that in our country a person needs at least $19,883,000$ soums per day (when 1 US dollar is equal to 10,463 soums). Correspondingly, 596,505 soums per person per month and $2,982,525$ soums per 5 people are required.

In addition, on September 24, 2020, at the 75th session of the UN General Assembly, the head of our state made proposals on a number of global issues, one of which was the fight against poverty.

In his speeches, the President noted that unrest persists in various parts of the world, conflicts and violence are on the rise, environmental disasters and other similar disasters exacerbate global problems of poverty, especially in the context of pandemics.
Given this critical economic situation, it is possible to employ a certain segment of the unemployed population through the development of women's entrepreneurship in the eradication of poverty and destitution in the country. This will contribute to the sustainable economic development of the country.

\section{Conclusions and suggestions}

For the formation and development of women's entrepreneurship, we must pay special attention to the following proposals:

- Consistent implementation of feminism, that is, the creation of equal opportunities based not on gender, but on the qualities, knowledge, skills and abilities of women. This will give a new impetus to the economic development of the country;

- Encouraging the employment of employed women through the unconditional implementation of preferential approaches of international financial corporations in supporting their entrepreneurship;

- Conduct separate research and study the problems of the Ministry of Labor and Employment in the recruitment of unemployed women in labor exchanges, and on this basis to improve employment services;

- In the formation of women's entrepreneurship, it is necessary to pay attention to the biological differences between men and women. But not to discriminate against women entrepreneurs, especially those with disabilities. They need to be provided with state social support, infrastructure (elevators, ramps, customized public transport) and amenities in the form of certain working conditions. Certain conditions are also necessary for the realization of the rights of women entrepreneurs.

From the above, we can conclude that the role of women entrepreneurs in the socio-economic development of our country is invaluable. In the renewed Uzbekistan, women's entrepreneurship makes a worthy contribution to the innovative development of enterprises and organizations at the macro and micro levels.

\section{References}

[1] Speech of the President of the Republic of Uzbekistan Shavkat Mirziyoyev at the 75th session of the United Nations General Assembly. - "Khalq so'zi" newspaper, September 24, 2020, No. 202 (7704)

[2] Address of the President of the Republic of Uzbekistan Shavkat Mirziyoyev to the Oliy Majlis.T :: Tasvir, 2020

[3] Sh.Mirziyoev. Critical analysis, strict discipline and personal responsibility should be the daily rule of every leader.T .: Uzbekistan, 2018

[4] Resolution of the President of the Republic of Uzbekistan Sh.M.Mirziyoev "On measures to improve and increase the efficiency of employment" No PP-3856.2018 
[5] A.Smith. Research on the nature and origins of the riches of peoples (I-III) .- M.: Nauka, 1992

[6] Dj.M.Keyns. The general theory of zanyatnosti and deneg. M., 1978

[7] Y.Shumpeter. History of economic analysis .: in 3tt. (per. s angl., under red Avtanomova V.S.). -M .: Ekonomisekaya shkola, 2004

[8] A.A.Razumova. Poverty in the system of labor market: methodology of analysis, modern situation, strategy of overcoming. Author's abstract of the dissertation for the degree of Doctor of Economic Sciences.-M: 2003

[9] A.Olmasov, A.Vahobov. Economic Theory.-T .: Sharq.2006 https://stanradar.com/news/full/34302zhenskoe-litso-uzbekistanskogo-biznesa.html

[10] Nabijanovich, D. B. (2019). Issues of support and stimulation of exporting enterprises and ways of their elimination. American Journal of Economics and Business Management, 2(3), 44-56.

[11] Xabibullayevich, U. L., Nabijanovich, B. D., \& Ibragimovna, F. E. (2020). Increasing effectiveness of economic educationprocessis basis for the development of qualification of entrepreneurship. Asian Journal of Multidimensional Research (AJMR), 9(3), 210215.

[12] Солиева, Г. А., Дедажанов, Б. Н., \& Каримжанова, Р. М. (2020). Туризм в Узбекистане и роль маркетинга в его развитии. Молодой ученый, (5), 132-134.

[13] Dedajanov, B. N., \& Ergasheva, F. I. (2019). ISSUES OF SUPPORT AND STIMULATION OF EXPORTING ENTERPRISES AND WAYS OF THEIR ELIMINATION. Вестник Российского экономического университета им. ГВ Плеханова. Вступление. Путь в науку, (3), 92103.

[14] Рашидов, Р. (2017). НЕКОТОРЫЕ ВОПРОСЫ ЭФФЕКТИВНОГО ИСПОЛЬЗОВАНИЯ ТЕХНИКИ В ХЛОПКОВОДСТВЕ В УЗБЕКИСТАНЕ. Общество и экономика, (3-4), 138-141.

[15] ALojonovich, R. R. (2016). Correlation between resource economy factors in cotton growing. Наука и образование сегодня, (6 (7)).

[16] Rahmatullo, R. (2016). Sectoral specificities by application of resource saving technology in cotton growing. Economics, (8 (17)).

[17] Rashidov, R. (2016). Correlation between resource economy factors in cotton growing. Наука и образование сегодня, (6), 68-70.

[18] Alojonovich, R. R. (2019). Economic efficiency of resource-saving technologies in the cotton industry system of indicators. International Journal of Scientific and Technology Research, 8(11), 38613863. 